\title{
Risk Based Bank Rating dalam Mengukur Tingkat Kesehatan Perbankan
}

\author{
Neny Tri Indrianasari ${ }^{1}$, Khoirul Ifa ${ }^{2}$ \\ STIE Widya Gama Lumajang ${ }^{12}$ \\ indriana85@gmail.com ${ }^{1}$
}

\begin{abstract}
Abstrak
Otoritas Jasa Keuangan menilai industri perbankan nasional dalam kondisi yang lebih baik ditunjukkan dengan beberapa indikator salah satunya keterlibatan pihak pemerintah dalam mewujudkan pertumbuhan ekonomi. Dengan kondisi perbankan yang semakin baik akan merimbas pada pertumbuhan Bank Perkreditan Rakyat Syariah. Penelitian ini bertujuan untuk mengetahui tingkat kesehatan bank BPR Syariah yang ada di Wilayah Jawa Timur dengan menggunakan metode Risk-Based Bank Rating. Penilaian dengan metode Risk-Based Bank Rating terdiri dari empat faktor risk profile, Good Corporate Governance, earning dan capital dari setiap bank. Penelitian ini menggunakan pendekatan kuantitatif dengan metode deskriptif untuk menganalisis rasio-rasio yang diukur. Jenis data yang digunakan adalah data time series tahun 2015 - 2017 . Sumber data diperoleh dari website Otoritas Jasa Keuangan (OJK). Teknik analisa data menggunakan analisis Risk Based Bank Rating (RBBR) terdiri dari empat faktor risk profile, Good Corporate Governance, earning dan capital. Penelitian ini menyimpulkan bahwa rata-rata secara keseluruhan nilai NPF Bank Perkreditan Rakyat Syariah (BPRS) sebesar 13,37\% dengan predikat tidak sehat, rata-rata secara keseluruhan nilai ROA Bank Perkreditan Rakyat Syariah (BPRS) sebesar $0,11 \%$ dengan predikat kurang sehat dan bahwa rata-rata secara keseluruhan nilai CAR Bank Perkreditan Rakyat Syariah (BPRS) sebesar 28,47\% dengan predikat sangat sehat.
\end{abstract}

\section{Kata Kunci: Perbankan, BPR Syariah, Risk Based Bank Rating}

\begin{abstract}
The Financial Services Authority assesses the national banking industry in better shape shown by some indicators, one of which the involvement of the Government in realizing economic growth. With the better banking conditions will merimbas Bank on growth Of Islamic Peoples. This research aims to know the level of health of bank Syariah BPR in the East Java by using methods of Risk-Based Bank Rating. The assessment by the method of Risk-Based Bank Rating consists of four factors of risk profile, Good Corporate Governance, earning and capital of each bank. This research uses descriptive method quantitative approach to analyse the ratio-the ratio of the measured. The data type used is the time series data of the year 2015 - 2017. Source data obtained from the Financial Services Authority website (OJK). Data analysis techniques using analysis of Risk Based Bank Rating (RBBR) consist of four factor risk profile, Good Corporate Governance, earning and capital. The study concluded that the overall average value of NPF Bank Of Islamic People (BPRS) of 13.37\% unhealthy, with an average overall rating Of Sharia Rural Banks ROA (BPRS) of $0.11 \%$ with the predicate less healthy and that the average overall rating Of Sharia Rural Banks CAR (BPRS) amounted to $28.47 \%$ with very healthy.
\end{abstract}

Keywords: Banking, BPR Sharia, Risk Based Bank Rating 


\section{PENDAHULUAN}

Otoritas Jasa Keuangan (OJK) menilai industri perbankan nasional dalam kondisi yang lebih baik ditunjukkan dengan beberapa indikator salah satunya keterlibatan pihak pemerintah dalam mewujudkan pertumbuhan ekonomi. Dengan kondisi perbankan yang semakin baik akan merimbas pada pertumbuhan Bank Perkreditan Rakyat. Hal ini dapat dilihat dari perkembangan industri Bank Perkreditan Rakyat (BPR) pada April 2017 tumbuh positif dengan total aset sebesar Rp115,2 triliun atau meningkat 10,18\% (http://finansial.bisnis.com).

Meskipun jumlah aset mengalami pertumbuhan, masih terdapat masalah internal dan eksternal. Antara lain permodalan yang masih terbatas, tata kelola, kualitas dan kuantitas sumber daya manusia (SDM), mahalnya biaya dana yang berdampak ke suku bunga, serta produk dan layanan yang belum variatif. Sementara dari sisi eksternal, tantangan yang dihadapi adalah persaingan yang semakin meningkat. Saat ini segmen mikro dan kecil yang selama ini merupakan target pasar BPR juga dilayani oleh lembaga jasa keuangan lain selain bank seperti lembaga keuangan mikro (LKM), Koperasi simpan pinjam (KSP), credit union dan fintech.

Adanya keterbatasan dari Bank Perkreditan Rakyat (BPR) tersebut Bank Perkreditan Rakyat (BPR) perlu mengetahui tingkat kesehatan bank dengan menggunakan teknik Risk-based Bank Rating. Kebijakan penilaian tingkat kesehatan bank kembali diperbarui oleh Bank Indonesia pada tanggal 25 Oktober 2011 dengan mengeluarkan Peraturan Bank Indonesia No.13/PBI/2011. Peraturan baru ini merupakan penyempurnaan dari metode CAMELS yang sebelumnya digunakan. Peraturan ini adalah penyempurnaan dari metode CAMELS yang disebut dengan metode Risk-Based Bank Rating (RBBR). Metode RBBR terdiri dari beberapa faktor yaitu Risk Profile, Good Corporate Governance $(G C G)$, Earning, dan Capital. Metode RBBR merupakan pengembangan yang dilakukan oleh Bank Indonesia dengan memperhatikan kebutuhan serta perkembangan industri perbankan yang tidak hanya melibatkan skala kecil usaha.

Metode Risk Based Bank Rating (RBBR) mewajibkan bank baik secara individual maupun konsolidasi untuk melakukan penilaian tingkat kesehatan bank dengan menggunakan pendekatan risiko. Pada metode Risk Based Bank Rating (RBBR) analisis dilakukan terhadap kinerja, profil risiko, permasalahan yang dihadapi dan prospek perkembangan bank secara komperehensif. Analisis yang digunakan berbasis pada prinsip manajemen risiko. Pentingnya menjaga kesehatan bank bertujuan agar nasabah tetap memberikan kepercayaan kepada bank yang bersangkutan. Suatu bank besar yang mengalami kebangkrutan dapat menyebabkan penarikan dana secara tiba-tiba kepada bank lainnya. (Latumaerissa, 2012:144)

Menurut Dea (2017) faktor profil risiko menunjukkan bahwa bank milik pemerintah pusat memiliki rata-rata NPL dibawah 5\%. Hasil penilaian rasio ROA dan NIM menunjukkan rata-rata rentabilitas bank milik pemerintah pusat sangat memadai untuk permodalan bank. Hasil penilaian rasio CAR menunjukkan keseluruhan berpredikat sangat sehat yang menunjukkan bank mampu memenuhi kewajiban penyediaan modal. Sedangkan menurut Nardi Sunardi (2018) risiko Likuiditas menunjukkan bahwa rata-rata secara keseluruhan Financing to Deposit Ratio (FDR) dengan predikat Kurang Sehat, Good Coorporate Governance diperoleh hasil analisis self assessment yaitu dengan nilai komposit $1.83 \%$ dengan predikat Baik, faktor earning (rentabilitas) dengan Return On Asset (ROA) predikat Kurang Sehat, analisis modal dengan Capital Adequency Ratio (CAR) predikat Sangat Sehat, Metode Risk Based Bank Rating (RBBR) menunjukkan nilai PK 1 dengan predikat Cukup Sehat. berdasarkan Pasal 2 Peraturan bank Indonesia No. 13/1/PBI/2011 dan sesuai yang telah dijelaskan dalam SE BI No. 13/24/DPNP 25 Oktober 2011. 
Dari hal tersebut BPR Syariah diambil sebagai bahan kajian penelitian, karena Bank Perkreditan Rakyat syariah (BPRS) sebagai lembaga perantara keuangan yang beroperasi atas dasar prinsipprinsip syariah Islam sangat compatible dengan ketimpangan sosial, kemiskinan dan ketidakadilan sosial ekonomi. Dalam mengemban misi tersebut, tidak berarti BPRS mengabaikan kesehatan usaha bank itu sendiri, melainkan keduanya harus berjalan secara proporsional. Dalam menyalurkan pembiayaan kepada masyarakat, bank syariah sebagai sebuah lembaga bisnis yang berpegang pada nilai-nilai syariah sudah barang tentu tidak ingin mengalami kerugian, sebagaimana terdapat halnya lembaga-lembaga bisnis lain. Karena itu, bank syariah memiliki standar atau berpedoman pada prinsip kehati-hatian (prudential principles). Penetapan rambu-rambu kesehatan perbankan bertujuan agar bank sebagai financial intermediary institution yang melakukan kegiatan perkreditan, yang menggunakan dana masyarakat dan pihak ketiga lainnya, harus selalu dalam keadaan sehat. Sesuai dengan pasal 29 ayat (2) Undang-undang No. 10 tahun 1998 Jo. Undangundang No. 7 tahun 1992, bahwa bank wajib memelihara tingkat kesehatannya sesuai dengan ketentuan kecukupan modal, kualitas aset, kualitas manajemen, likuiditas, rentabilitas, solvabilitas, dan aspek lain yang berhubungan dengan usaha bank, dan wajib melakukan kegiatan usaha dengan prinsip kehati-hatian.

Pengaturan sistem penilaian tingkat kesehatan BPRS dalam Peraturan Bank Indonesia Nomor : 9/17/PBI/2007 tentang Sistem Penilaian Tingkat Kesehatan Bank Perkreditan Rakyat Berdasarkan Prinsip Syariah, dilakukan melalui pendekatan kualitatif dan kuantitatif dari faktor permodalan, kualitas aset, rentabilitas dan likuiditas, sedangkan penilaian atas komponen dari faktor manajemen dilakukan secara kualitatif melalui analisis dengan mempertimbangkan indikator pendukung termasuk kepatuhan terhadap prinsip syariah (syariah compliance). Hasil akhir penilaian dimaksud dapat digunakan BPRS sebagai sarana menetapkan strategi usaha di waktu yang akan datang, dan bagi Bank Indonesia dapat digunakan sebagai sarana penetapan dan implementasi strategi pembinaan dan pengawasan.

BPR Syariah merupakan perusahaan perbankan yang memiliki karakteristik berbeda dibandingkan dengan bank konvensional. Eksistensi BPR Syariah dimaksudkan secara khusus untuk menjangkau masyarakat dari golongan ekonomi lemah dan pengusaha kecil baik di pedesaan maupun di perkotaan. Dalam hal lainnya, BPR Syariah cenderung menerapkan mekanisme pelayanan jasa yang lebih sederhana, tingkat suku bunga yang lebih tinggi, dan lebih bersikap proaktif dalam mencari nasabah dibandingkan dengan bank konvensional. Dengan perbedaan karakteristik tersebut BPR Syariah perlu ditinjau secara khusus, dimana tinjauan terhadap bank konvensional belum tentu sesuai dengan kondisi BPR Syariah.

\section{METODE PENELITIAN}

Jenis penelitian ini menggunakan pendekatan kuantitatif deskriptif untuk menganalisis rasio-rasio yang diukur. Metode ini bertujuan untuk mendeskripsikan data yang terkumpul secara sistematis dan akurat, sehingga dengan menggunakan metode ini, diharapkan dapat menggambarkan keadaan secara jelas mengenai analisis tingkat kesehatan perbankan menggunakan metode Risk-Based Bank Rating. Objek dalam penelitian ini adalah Bank Perkreditan Rakyat Syariah yang ada di wilayah Jawa Timur selama 3 tahun yaitu tahun 2015 sampai dengan tahun 2017. Teknik pengumpulan data menggunakan studi dokumentasi dengan mengumpulkan data sekunder, mencatat, dan mengolah data yang berkaitan dengan penelitian ini. Teknik analisa data dalam penelitian ini dengan menggunakan metode RBBR (Risk-Based Bank Rating). Metode tersebut disesuaikan dengan pedoman yang diberikan oleh Bank Indonesia kemudian dihitunglah skor dari masing- 
masing variabel yang selanjutnya dibuat peringkat sesuai peringkat yang telah disusun oleh Bank Indonesia.

\section{HASIL DAN PEMBAHASAN}

Risk Profile (profil risiko) menjadi dasar penilaian tingkat bank pada saat ini dikarenakan setiap kegiatan yang dilaksanakan oleh bank sangat memungkinkan akan timbulnya risiko. Bank Indonesia menjelaskan risiko-risiko yang diperhitungkan dalam menilai tingkat kesehatan bank dengan metode Risk-Based Bank Rating dalam Surat Edaran Bank Indonesia No 13/24/DNPN pada tanggal 25 Oktober 2013 terdiri dari : a. Risiko Kredit adalah risiko akibat kegagalan debitur dan/atau pihak lain dalam memenuhi kewajiban membayar angsuran pokok ataupun bunga sebagaimana perjanjian yang telah disepakati pada Bank. Berdasarkan tabel 1 menunjukkan bahwa rata-rata secara keseluruhan nilai NPF Bank Perkreditan Rakyat Syariah (BPRS) sebesar 13,37\% dengan predikat tidak sehat. Untuk nilai NPF tertinggi terlihat pada Kabupaten Pasuruan yaitu PT BPRS Jabal Tsur sebesar 54,96\%, sedangkan untuk nilai NPF terendah terlihat pada Kabupaten Sumenep yaitu PT BPRS Bhakti Sumekar sebesar 1,94\%. Nilai NPF tinggi mengindikasikan terjadinya kredit macet karena diluar kontrol nasabah. Sehingga pembiayaan tidak tumbuh dan mengakibatkan nilai NPF naik. Kredit bermasalah didefinisikan sebagai risiko yang dikaitkan dengan kemungkinan kegagalan klien membayar kewajibannya atau risiko dimana debitur tidak dapat melunasi hutangnya. Kriteria rasio NPF analog dengan NPL sesuai Peraturan Bank Indonesia No.17/11/PBI/2015 dibawah 5\% (Khatimah, 2009: 5). Bank dapat menjadi salah satu faktor penyebab baik atau buruknya kualitas kredit yang diberikan. Apabila dalam suatu pemberian kredit dilaksanakan dengan prinsip kehati-hatian, dan terhadap kredit yang telah diberikan tersebut dilakukan pengawasan dengan baik, maka kualitas kredit suatu Bank akan tetap terjaga dengan baik. Sebaliknya apabila pemberian kredit tidak dilakukan dengan baik, maka kualitas kredit suatu Bank akan dengan mudah menjadi buruk. Akan tetapi, penyebab nilai NPF yang tinggi tidak hanya karena terjadi gejolak ekonomi saja banyak faktor penyebab di luar itu. Misalnya perbankan syariah masih banyak yang belum menjangkau ke daerah-daerah pelosok. Meskipun nilai NPF tinggi apabila ditunjang dengan nilai CAR yang cukup maka BPR Syariah tersebut masih dalam batas aman.

Tabel 1. Perhitungan NPF BPR Syariah Provinsi Jawa Timur Periode 2015-2017

\begin{tabular}{|c|c|c|c|c|c|c|}
\hline \multirow{2}{*}{ No } & \multirow{2}{*}{ Kabupaten/Kota } & \multicolumn{3}{|c|}{ NPF } & \multirow{2}{*}{$\begin{array}{c}\text { Rata- } \\
\text { rata }\end{array}$} & \multirow{2}{*}{ Predikat } \\
\hline & & 2015 & 2016 & 2017 & & \\
\hline \multirow[t]{4}{*}{1} & Kabupaten Gresik & & & & & \\
\hline & PT BPRS Amanah Sejahtera & $1.15 \%$ & $0.89 \%$ & $44.15 \%$ & $15.40 \%$ & Tidak sehat \\
\hline & PT BPRS Mandiri Mitra & & & & & \\
\hline & Sukses & $2.80 \%$ & $6.65 \%$ & $4.41 \%$ & $4.62 \%$ & Sehat \\
\hline \multirow[t]{3}{*}{2} & Kabupaten Jember & & & & & \\
\hline & PT BPRS Asri Madani & & & & & \\
\hline & Nusantara & $1.78 \%$ & $3.83 \%$ & $4.67 \%$ & $3.43 \%$ & Sehat \\
\hline \multirow[t]{2}{*}{3} & Kabupaten Jombang & & & & & \\
\hline & PT BPRS Lantabur Tebuireng & $7.66 \%$ & $6.33 \%$ & $3.38 \%$ & $5.79 \%$ & Cukup sehat \\
\hline \multirow[t]{3}{*}{4} & Kabupaten Kediri & & & & & \\
\hline & PT BPRS Artha Pamenang & $4.68 \%$ & $3.29 \%$ & $3.19 \%$ & $3.72 \%$ & Sehat \\
\hline & PT BPRS Rahma Syariah & $20.26 \%$ & $22.43 \%$ & $11.74 \%$ & $18.14 \%$ & Tidak sehat \\
\hline \multirow[t]{2}{*}{5} & Kabupaten Lamongan & & & & & \\
\hline & PT BPRS Madinah & $3.24 \%$ & $2.47 \%$ & $4.05 \%$ & $3.26 \%$ & Sehat \\
\hline
\end{tabular}


6 Kabupaten Magetan

PT BPRS Syariah Magetan

$0.47 \% \quad 2.53 \% \quad 3.83 \% \quad 2.28 \% \quad$ Sehat

7 Kabupaten Malang

PT BPRS Bhakti Haji

PT BPRS Bumi Rinjani

Kepanjen

$1.65 \% \quad 8.78 \% \quad 4.68 \% \quad 8.37 \% \quad$ Kurang sehat

Kabupaten Pamekasan

BPRS Sarana Prima Mandiri

$4.97 \% \quad 4.82 \% \quad 3.81 \% \quad 4.53 \% \quad$ Sehat

$12.34 \% \quad 11.86 \% \quad 6.47 \% \quad 10.22 \% \quad$ Kurang sehat

9 Kabupaten Pasuruan

BPRS Daya Artha Mentari

BPRS Jabal Tsur

BPRS Ummu

$29.94 \% \quad 32.19 \%$

$35.57 \%$

$32.57 \%$

Tidak sehat

$44.81 \%$

$50.21 \%$

$69.86 \%$

$54.96 \%$

Tidak sehat

$32.15 \%$

$32.26 \%$

$30.10 \%$

$31.51 \%$

Tidak sehat

10 Kabupaten Ponorogo

PT BPRS Al Mabrur Babadan

$3.41 \% \quad 6.00 \% \quad 6.98 \%$

$5.47 \%$

Cukup sehat

11 Kabupaten Probolinggo

PT BPRS Bumi Rinjani

Probolinggo

$21.72 \%$

$36.92 \%$

$39.65 \%$

$32.76 \%$

Tidak sehat

12 Kabupaten Sampang

PT BPRS Bakti Artha Sejahtera

Sampang

$7.41 \% \quad 7.83 \% \quad 17.58 \% \quad 10.94 \% \quad$ Kurang sehat

13 Kabupaten Sidoarjo

PT BPRS Annisa Mukti

PT BPRS Baktimakmur Indah

$0.92 \% \quad 1.82 \% \quad 1.89 \%$

$1.55 \%$

Sangat sehat

$7.14 \%$

$9.39 \%$

$8.80 \%$

$8.44 \%$

Kurang sehat

PT BPRS Unawi Barokah

$0.91 \%$

$7.65 \% \quad 13.38 \%$

$7.31 \%$

Cukup sehat

14 Kabupaten Situbondo

PT BPRS Situbondo

15 Kabupaten Sumenep

PT BPRS Bhakti Sumekar

$4.90 \%$

$4.97 \%$

$7.99 \%$

$5.95 \%$

Cukup sehat

$1.36 \%$

$2.09 \%$

$2.38 \%$

$1.94 \%$

Sangat sehat

16 Kota Batu

PT BPRS Bumi Rinjani Batu

$39.91 \% \quad 40.92 \% \quad 39.48 \%$

$40.11 \%$

Tidak sehat

17 Kota Kediri

PT BPRS Tanmiya Artha

$30.34 \%$

$21.00 \% \quad 11.12 \%$

$20.82 \%$

Tidak sehat

18 Kota Malang

PT BPRS Mitra Harmoni Kota

Malang

$4.82 \%$

$5.07 \%$

$4.60 \%$

$4.83 \%$

Sehat

19 Kota Mojokerto

PT BPRS Kota Mojokerto

$2.43 \%$

$5.08 \%$

$3.95 \%$

$3.82 \%$

Sehat

20 Kota Pasuruan

PT BPRS Al Hidayah

$54.82 \% \quad 0 \% \quad 0 \% \quad 18.27 \% \quad$ Tidak sehat
Rata-rata

$13.26 \%$

Sumber : Data Diolah, 2019

Berdasarkan pernyataan Taswan (2010:165) Penilaian tingkat kesehatan bank yang melihat kemampuan bank dalam menghasilkan laba. Penilaian faktor rentabilitas bank dapat menggunakan parameter Return On Asset (ROA) merupakan rasio profitabilitas yang menunjukkan kemampuan bank dalam memperoleh laba ataupun keuntungan dengan cara mengoptimalkan penggunaan aset 
yang dimiliki. Berdasarkan tabel 2 menunjukkan bahwa rata-rata secara keseluruhan nilai ROA Bank Perkreditan Rakyat Syariah (BPRS) sebesar 0,11\% dengan predikat kurang sehat. Untuk nilai ROA tertinggi terlihat pada Kabupaten Sidoarjo yaitu PT BPRS Annisa Mukti sebesar 4,88\%, sedangkan untuk nilai ROA terendah terlihat pada Kota Batu yaitu PT BPRS Bumi Rinjani Batu sebesar $-12,81 \%$. Return on Asset merupakan perbandingan antara laba sebelum bunga dan pajak dengan total aktiva yang dimiliki perusahaan. Semakin besar Return on Assets (ROA) suatu bank, semakin besar pula tingkat keuntungan yang dicapai bank tersebut dan semakin baik pula posisi bank tersebut dari segi penggunaan aset. Return on Asset (ROA) yang positif menunjukkan bahwa dari total aktiva yang dipergunakan untuk beroperasi, perusahaan mampu memberikan laba bagi perusahaan. Sebaliknya apabila return on asset (ROA) yang negatif disebabkan laba perusahaan dalam kondisi negatif pula atau rugi, hal ini menunjukkan kemampuan dari modal yang diinvestasikan secara keseluruhan belum mampu untuk menghasilkan laba. Jadi jika suatu perusahaan mempunyai Return on Assets (ROA) yang tinggi maka perusahaan tersebut berpeluang besar dalam meningkatkan pertumbuhan.Tetapi jika total aktiva yang digunakan perusahaan tidak memberikan laba maka perusahaan akan mengalami kerugian dan akan menghambat pertumbuhan perusahaan tersebut. Return on Asset (ROA) menggambarkan sejauhmana tingkat pengembalian dari seluruh asset yang dimiliki perusahaan.

Tabel 2. Perhitungan ROA BPR Syariah Provinsi Jawa Timur Periode 2015-2017

\begin{tabular}{|c|c|c|c|c|c|c|}
\hline \multirow{2}{*}{ No } & \multirow{2}{*}{ Kabupaten/Kota } & \multicolumn{3}{|c|}{ ROA } & \multirow{2}{*}{$\begin{array}{c}\text { Rata- } \\
\text { rata }\end{array}$} & \multirow{2}{*}{ Predikat } \\
\hline & & 2015 & 2016 & 2017 & & \\
\hline \multirow[t]{3}{*}{1} & Kabupaten Gresik & & & & & \\
\hline & PT BPRS Amanah Sejahtera & $-3.08 \%$ & $2.26 \%$ & $0.02 \%$ & $-0.27 \%$ & Tidak sehat \\
\hline & $\begin{array}{l}\text { PT BPRS Mandiri Mitra } \\
\text { Sukses }\end{array}$ & $0.01 \%$ & $0.48 \%$ & $0.44 \%$ & $0.31 \%$ & Kurang sehat \\
\hline \multirow[t]{2}{*}{2} & Kabupaten Jember & & & & & \\
\hline & $\begin{array}{l}\text { PT BPRS Asri Madani } \\
\text { Nusantara }\end{array}$ & $3.45 \%$ & $1.33 \%$ & $2.14 \%$ & $2.31 \%$ & Sangat sehat \\
\hline \multirow[t]{2}{*}{3} & $\begin{array}{l}\text { Kabupaten Jombang } \\
\text { PT BPRS Lantabur }\end{array}$ & & & & & \\
\hline & Tebuireng & $4.49 \%$ & $4.26 \%$ & $5.71 \%$ & $4.82 \%$ & Sangat sehat \\
\hline \multirow[t]{3}{*}{4} & Kabupaten Kediri & & & & & \\
\hline & PT BPRS Artha Pamenang & $3.62 \%$ & $4.74 \%$ & $4.94 \%$ & $4.43 \%$ & Sangat sehat \\
\hline & PT BPRS Rahma Syariah & $0.64 \%$ & $0.52 \%$ & $-0.85 \%$ & $0.10 \%$ & Kurang sehat \\
\hline \multirow[t]{2}{*}{5} & Kabupaten Lamongan & & & & & \\
\hline & PT BPRS Madinah & $5.26 \%$ & $3.32 \%$ & $2.58 \%$ & $3.72 \%$ & Sangat sehat \\
\hline \multirow[t]{2}{*}{6} & Kabupaten Magetan & & & & & \\
\hline & PT BPRS Syariah Magetan & $2.38 \%$ & $3.58 \%$ & $5.83 \%$ & $3.93 \%$ & Sangat sehat \\
\hline \multirow[t]{3}{*}{7} & Kabupaten Malang & & & & & \\
\hline & $\begin{array}{l}\text { PT BPRS Bhakti Haji } \\
\text { PT BPRS Bumi Rinjani }\end{array}$ & $-3.24 \%$ & $-2.61 \%$ & $-6.33 \%$ & $-4.06 \%$ & Tidak sehat \\
\hline & Kepanjen & $4.24 \%$ & $4.35 \%$ & $4.51 \%$ & $4.37 \%$ & Sangat sehat \\
\hline \multirow[t]{2}{*}{8} & Kabupaten Pamekasan & & & & & \\
\hline & $\begin{array}{l}\text { BPRS Sarana Prima Mandiri } \\
\text { Kabupaten Pasuruan }\end{array}$ & $1.39 \%$ & $0.29 \%$ & $1.44 \%$ & $1.04 \%$ & Cukup sehat \\
\hline \multirow{3}{*}{9} & BPRS Daya Artha Mentari & $0.19 \%$ & $-4.05 \%$ & $-2.12 \%$ & $-1.99 \%$ & Tidak sehat \\
\hline & BPRS Jabal Tsur & $-2.10 \%$ & $-3.82 \%$ & $-3.54 \%$ & $-3.15 \%$ & Tidak sehat \\
\hline & BPRS Ummu & $-16.86 \%$ & $0.10 \%$ & $1.01 \%$ & $-5.25 \%$ & Tidak sehat \\
\hline
\end{tabular}


PT BPRS Al Mabrur

Babadan

11 Kabupaten Probolinggo

PT BPRS Bumi Rinjani

Probolinggo

12 Kabupaten Sampang

PT BPRS Bakti Artha

Sejahtera Sampang

13 Kabupaten Sidoarjo

PT BPRS Annisa Mukti

PT BPRS Baktimakmur

Indah

PT BPRS Unawi Barokah

14 Kabupaten Situbondo

PT BPRS Situbondo

15 Kabupaten Sumenep

PT BPRS Bhakti Sumekar

16 Kota Batu

PT BPRS Bumi Rinjani Batu

17 Kota Kediri

PT BPRS Tanmiya Artha

18 Kota Malang

PT BPRS Mitra Harmoni

19 Kota Mojokerto

PT BPRS Kota Mojokerto

20 Kota Pasuruan

PT BPRS Al Hidayah

Rata-rata
$4.43 \% \quad 4.08 \% \quad 3.40 \% \quad 3.97 \% \quad$ Sangat sehat

$-7.94 \% \quad-4.60 \% \quad-8.50 \% \quad-7.01 \quad$ Tidak sehat

$3.19 \% \quad 3.72 \% \quad 2.91 \% \quad 3.27 \% \quad$ Sangat sehat

$6.55 \% \quad 5.10 \% \quad 2.99 \% \quad 4.88 \% \quad$ Sangat sehat

$5.33 \% \quad 3.35 \% \quad 3.48 \% \quad 4.05 \% \quad$ Sangat sehat

$-0.51 \% \quad-6.01 \% \quad-6.35 \% \quad-4.29 \%$ Tidak sehat

$4.03 \% \quad 4.33 \% \quad 4.64 \% \quad 4.33 \% \quad$ Sangat sehat

$3.55 \% \quad 3.05 \% \quad 2.10 \% \quad 2.90 \% \quad$ Sangat sehat

$-18.80 \% \quad 20.30 \% \quad 0.66 \% \quad-12.81 \% \quad$ Tidak sehat

$2.89 \% \quad 3.82 \% \quad 2.91 \% \quad 3.21 \% \quad$ Sangat sehat

$0.54 \% \quad 0.63 \% \quad 2.65 \% \quad 1.27 \%$ Sehat

$1.31 \% \quad 1.45 \% \quad 1.70 \% \quad 1.49 \%$ Sehat

$1.31 \% \quad 1.45 \% \quad 1.70 \% \quad 1.49 \%$ Sehat

$-38.06 \%$

\begin{tabular}{rrrl}
$0 \%$ & $0 \%$ & $-12.69 \%$ & Tidak sehat \\
$0.50 \%$ & $1.05 \%$ & $0.11 \%$ & Kurang sehat \\
\hline
\end{tabular}

Sumber : Data Diolah, 2019

Rasio yang dapat digunakan untuk mengukur kecukupan modal yang dimiliki bank adalah Capital Adequacy Ratio (CAR). Berdasarkan SE BI No 26/2/BPPP mengatur bahwa kewajiban penyediaan modal minimum atau CAR diukur dari dari persentase tertentu terhadap Aktiva Tertimbang. Menurut Risiko (ATMR) sebesar 8\% dari ATMR. Berdasarkan tabel 3 menunjukkan bahwa ratarata secara keseluruhan nilai CAR Bank Perkreditan Rakyat Syariah (BPRS) sebesar 28,47\% dengan predikat sangat sehat. Untuk nilai CAR tertinggi terlihat pada Kabupaten Situbondo yaitu PT BPRS Situbondo sebesar 88,97\%, sedangkan untuk nilai CAR terendah terlihat pada Kota Pasuaruan yaitu PT BPRS Al Hidayah sebesar -8,82\%. Modal merupakan salah satu faktor penting dalam rangka pengembangan usaha bisnis dan menampung resiko kerugian, semakin tinggi Capital Adequacy Ratio (CAR) maka semakin kuat kemampuan bank tersebut untuk menanggung resiko dari setiap kredit/aktiva produktif yang berisiko. Modal ini digunakan untuk menjaga kepercayaan masyarakat terhadap kinerja bank. Hal ini wajar karena bisnis perbankan adalah bisnis yang berdasarkan kepercayaan. Selain itu adanya berbagai bentuk risiko yang besar yang mungkin dapat terjadi pada bank. Latumerissa (2012) menyatakan bahwa tingkat atau jumlah modal bank yang memadai (capitaladequacy) diperlukan untuk meningkatkan ketahanan dan efisiensi. Jumlah modal yang memadai memegang peranan penting dalam memberikan rasa aman kepada calon atau para penitip uang. Penyebab nilai ROA mengalami menurun atau negatif karena kenaikan tingkat suku 
bunga yang secara umum menyebabkan Peningkatan Cadangan Kerugian Penurunan Nilai Bank Perkreditan Rakyat Syariah.

Tabel 3. Perhitungan CAR BPR Syariah Provinsi Jawa Timur Periode 2015-2017

\begin{tabular}{|c|c|c|c|c|c|c|}
\hline \multirow{2}{*}{ No } & \multirow{2}{*}{ Kabupaten/Kota } & \multicolumn{3}{|c|}{ CAR } & \multirow{2}{*}{$\begin{array}{c}\text { Rata- } \\
\text { rata }\end{array}$} & \multirow{2}{*}{ Predikat } \\
\hline & & 2015 & 2016 & 2017 & & \\
\hline \multirow[t]{3}{*}{1} & Kabupaten Gresik & & & & & \\
\hline & PT BPRS Amanah Sejahtera & $15.36 \%$ & $11.21 \%$ & $9.35 \%$ & $11.98 \%$ & Sehat \\
\hline & PT BPRS Mandiri Mitra Sukses & $17.02 \%$ & $9.74 \%$ & $8.69 \%$ & $11.82 \%$ & Sehat \\
\hline \multirow[t]{2}{*}{2} & Kabupaten Jember & & & & & \\
\hline & $\begin{array}{l}\text { PT BPRS Asri Madani } \\
\text { Nusantara }\end{array}$ & $17.09 \%$ & $15.07 \%$ & $15.36 \%$ & $15.84 \%$ & Sangat sehat \\
\hline \multirow[t]{2}{*}{3} & Kabupaten Jombang & & & & & \\
\hline & $\begin{array}{l}\text { PT BPRS Lantabur Tebuireng } \\
\text { Kabupaten Kediri }\end{array}$ & $10.80 \%$ & $9.40 \%$ & $8.74 \%$ & $9.65 \%$ & Sehat \\
\hline \multirow{2}{*}{4} & PT BPRS Artha Pamenang & $18.49 \%$ & $12.78 \%$ & $12.86 \%$ & $14.71 \%$ & Sangat sehat \\
\hline & PT BPRS Rahma Syariah & $37.42 \%$ & $59.77 \%$ & $59.36 \%$ & $52.18 \%$ & Sangat sehat \\
\hline \multirow[t]{2}{*}{5} & Kabupaten Lamongan & & & & & \\
\hline & PT BPRS Madinah & $16.03 \%$ & $21.71 \%$ & $17.46 \%$ & $18.40 \%$ & Sangat sehat \\
\hline \multirow[t]{2}{*}{6} & Kabupaten Magetan & & & & & \\
\hline & PT BPRS Syariah Magetan & $55.51 \%$ & $66.25 \%$ & $68.95 \%$ & $63.57 \%$ & Sangat sehat \\
\hline \multirow[t]{3}{*}{7} & Kabupaten Malang & & & & & \\
\hline & $\begin{array}{l}\text { PT BPRS Bhakti Haji } \\
\text { PT BPRS Bumi Rinjani }\end{array}$ & $37.75 \%$ & $34.46 \%$ & $32.97 \%$ & $35.06 \%$ & Sangat sehat \\
\hline & Kepanjen & $8.35 \%$ & $9.77 \%$ & $8.95 \%$ & $9.03 \%$ & Sehat \\
\hline \multirow[t]{2}{*}{8} & Kabupaten Pamekasan & & & & & \\
\hline & BPRS Sarana Prima Mandiri & $13.34 \%$ & $13.78 \%$ & $10.41 \%$ & $12.51 \%$ & Sangat sehat \\
\hline \multirow[t]{4}{*}{9} & Kabupaten Pasuruan & & & & & \\
\hline & BPRS Daya Artha Mentari & $13.84 \%$ & $10.86 \%$ & $17.67 \%$ & $14.12 \%$ & Sangat \\
\hline & BPRS Jabal Tsur & $8.71 \%$ & $11.13 \%$ & $23.83 \%$ & $14.56 \%$ & Sangat sehat \\
\hline & BPRS Ummu & $30.44 \%$ & $46.52 \%$ & $45.18 \%$ & $40.71 \%$ & Sangat sehat \\
\hline 10 & Kabupaten Por & & & & & \\
\hline \multirow[t]{2}{*}{11} & $\begin{array}{l}\text { PT BPRS Al Mabrur Babadan } \\
\text { Kabupaten Probolinggo } \\
\text { PT BPRS Bumi Rinjani }\end{array}$ & $32.31 \%$ & $29.15 \%$ & $30.79 \%$ & $30.75 \%$ & Sangat sehat \\
\hline & Probolinggo & $17.74 \%$ & $20.07 \%$ & $46.10 \%$ & $27.97 \%$ & Sangat sehat \\
\hline \multirow[t]{2}{*}{12} & $\begin{array}{l}\text { Kabupaten Sampang } \\
\text { PT BPRS Bakti Artha Sejahtera }\end{array}$ & & & & & \\
\hline & Sampang & $22.70 \%$ & $27.11 \%$ & $29.09 \%$ & $26.30 \%$ & Sangat sehat \\
\hline \multirow[t]{4}{*}{13} & Kabupaten Sidoarjo & & & & & \\
\hline & PT BPRS Annisa Mukti & $26.08 \%$ & $45.98 \%$ & $43.77 \%$ & $38.61 \%$ & Sangat sehat \\
\hline & PT BPRS Baktimakmur Indah & $19.73 \%$ & $20.99 \%$ & $19.53 \%$ & $20.08 \%$ & Sangat sehat \\
\hline & PT BPRS Unawi Barokah & $44.99 \%$ & $40.80 \%$ & $56.62 \%$ & $47.47 \%$ & Sangat sehat \\
\hline \multirow[t]{2}{*}{14} & Kabupaten Situbondo & & & & & \\
\hline & PT BPRS Situbondo & $93.98 \%$ & $90.17 \%$ & $82.76 \%$ & $88.97 \%$ & Sangat sehat \\
\hline \multirow[t]{2}{*}{15} & Kabupaten Sumenep & & & & & \\
\hline & $\begin{array}{l}\text { PT BPRS Bhakti Sumekar } \\
\text { Kota Batu }\end{array}$ & $27.11 \%$ & $23.65 \%$ & $21.58 \%$ & $24.11 \%$ & Sangat sehat \\
\hline
\end{tabular}




\begin{tabular}{|c|c|c|c|c|c|c|}
\hline \multirow[b]{2}{*}{1} & PT BPRS Bumi Rinjani Batu & $31.99 \%$ & $53.25 \%$ & $94.78 \%$ & $60.01 \%$ & Sangat sehat \\
\hline & $\begin{array}{l}\text { Kota Kediri } \\
\text { PT BPRS Tanmiya Artha }\end{array}$ & $26.39 \%$ & $30.92 \%$ & $23.70 \%$ & $27.00 \%$ & Sangat sehat \\
\hline \multirow[t]{2}{*}{18} & Kota Malang & & & & & \\
\hline & $\begin{array}{l}\text { PT BPRS Mitra Harmoni Kota } \\
\text { Malang }\end{array}$ & $31.83 \%$ & $26.67 \%$ & $46.26 \%$ & $34.92 \%$ & Sangat sehat \\
\hline 19 & Kota Mojokerto & & & & & \\
\hline \multirow{4}{*}{20} & PT BPRS Kota Mojokerto & $30.44 \%$ & $31.89 \%$ & $19.48 \%$ & $27.27 \%$ & Sangat sehat \\
\hline & Kota Pasuruan & & & & & \\
\hline & PT BPRS Al Hidayah & $-26.46 \%$ & $0.00 \%$ & $0.00 \%$ & $-8.82 \%$ & Tidak sehat \\
\hline & Rata-rata & $25.15 \%$ & $28.63 \%$ & $31.64 \%$ & $28.47 \%$ & Sangat sehat \\
\hline
\end{tabular}

Sumber : Data Diolah, 2019

\section{KESIMPULAN}

Kesimpulan yang dihasilkan dalam penelitian ini bahwa rata-rata secara keseluruhan nilai NPF Bank Perkreditan Rakyat Syariah (BPRS) sebesar 13,37\% dengan predikat tidak sehat, rata-rata secara keseluruhan nilai ROA Bank Perkreditan Rakyat Syariah (BPRS) sebesar 0,11\% dengan predikat kurang sehat dan bahwa rata-rata secara keseluruhan nilai CAR Bank Perkreditan Rakyat Syariah (BPRS) sebesar 28,47\% dengan predikat sangat sehat. Disarankan kepada pihak BPR Syariah khususnya setiap Kabupaten di Provinsi Jawa Timur harus terus memperkuat kegiatan usahanya agar jumlah aset yang dimiliki semakin meningkat, jumlah penyaluran dana baik dalam bentuk kredit maupun penempatan di bank lain semakin meningkat, serta pendapatan operasional dan laba yang diperoleh untuk tahun tahun berikutnya semakin meningkat. Bagi peneliti selanjutnya, diharapkan dapat memperluas lokasi penelitian dan menambah variabel penelitian terutama pada variabel Good Corporate Governance yang akan diteliti sehingga dapat membandingkan dengan hasil pengujian yang ditemukan sebelumnya.

\section{DAFTAR PUSTAKA}

Alawiyah, T. (2016). Analisis Penilaian Tingkat Kesehatan Bank Dengan Menggunakan Metode RGEC Pada Bank Umum BUMN Yang Terdaftar Di Bursa Efek Indonesia Tahun 2012-2014. Pendidikan Dan Ekonomi.

Almilia, L. S., Shonhadji, N., \& Angraini. (2009). Faktor-Faktor yang Mempengaruhi Financial Sustainability Ratio pada Bank Umum Swast Nasional Non Devisa Periode 1995-2005. Jurnal Akuntansi Dan Keuangan.

Bank Indonesia. (2011). Peraturan Bank Indonesia Nomor: 13/1/PBI/2011 Tentang Penilaian Tingkat Kesehatan Bank Umum. Peraturan Bank Indonesia.

Febriyanti, S. (2016). Tingkat Kesehatan PT. Bank Negara Indonesia (Persero), Tbk. Menggunakan Metode RGEC Periode 2012-2014. Jurnal FinAcc.

Fitri, E. U. S. (2018). Analisis pengaruh tingkat kesehatan bank terhadap pertumbuhan laba pada perusahaan perbankan syariah yang terdaftar di bursa efek indonesia periode 2017. Journal Accounting.

Kaligis, Y. W. (2013). Analisis Tingkat Kesehatan Bank Dengan Menggunakan Metode Camel Pada Industri Perbankan Bumn Yang Terdaftar Di Bursa Efek Indonesia. Jurnal EMBA.

Kasmir. (2008). Bank dan Lembaga Keuangan Lainnya. In PT. Raja Grafindo Persada.

Kasmir. (2014). Laporan Keuangan Bank. In Manajemen Perbankan.

Latumaerissa, Julius.R. (2012). Bank dan Lembaga Keuangan Lain. Jakarta: Salemba Empat 
Luayyi, S. (2019). Analisis Risk Profile, Good Corporate Governance, Earning, Capital Guna Menilai Tingkat Kesehatan Bank. Jurnal Analisa Akuntansi Dan Perpajakan. https://doi.org/10.25139/jaap.v2i2.1394

Lukman dendawijaya. (2005). Manajamen Lembaga Keuangan. Jurnal Akuntansi.

Lutfiana, N., Yaningwati, F., \& Saifi, M. (2015). Analisis Tingkat Kesehatan Bank Dengan Menggunakan Metode Risk-Based Bank Rating (RBBR) (Studi pada Bank Umum Nasional Devisa dalam Pengawasan Tahun 2011- 2013). Jurnal Administrasi Bisnis.

Otoritas Jasa Keuangan. (2018). Statistik Perbankan Indonesia 2017. Ojk.

Paramartha, D. G. D. A., \& Mustanda, I. K. (2017). Ananlisis Penilaian Tingkat Kesehatan Bank Pada PT. Bank Central Asia. Tbk Berdasarkan Metode RGEC. E-Jurnal Manajemen Unud.

Saleo, R. (2017). Analisis Tingkat Kesehatan Bank dengan Menggunakan Metode CAMEL (Studi Kasus pada PT.Bank Mandiri tbk). Jurnal EMBA.

Suharsimi, A. (2010). Prosedur Penelitian: Suatu Pendekatan Praktik (Edisi Revisi). In Jakarta: Rineka Cipta. https://doi.org/10.1017/CBO9781107415324.004

Suhartono, D. A., \& Azizah, D. F. (2017). Analisis Tingkat Kesehatan Bank dengan Menggunakan Metode Risk Based Bank Rating. Jurnal Administrasi Bisnis. https://doi.org/10.1103/PhysRevB.84.144516

Susilo, Sri Y,dkk. (2000). Bank dan Lembaga Keuangan Lain. Jakarta: Salemba Empat

Taswan. (2010). Manajemen Perbankan: Konsep, Teknik, dan Aplikasi. In Yogyakarta: UPP STIM YKPN Yogyakarta.

Umar, H. (2008). Metodologi Penelitian Bisnis. In Metode Riset Bisnis.

Umar, Z. (2015). Analisis Tingkat Kesehatan Perbankan Konvensional dengan Metode Risk Profile , Earnings , Capital ( Studi kasus pada Perbankan Konvensional yang terdaftar di Bursa Efek Indonesia Tahun 2011-2014 ). ILMAN.

Widyaningrum, H. A. (2014). Analisis Tingkat Kesehatan Bank Dengan Menggunakan Metode Risk-Based Bank Rating (RBBR) (Studi pada Bank yang Terdaftar di Bursa Efek Indonesia dalam IHSG Sub Sektor Perbankan Tahun 2012). Jurnal Administrasi Bisnis. 